\title{
Factors Affecting Car Financing: A Case Study of Conventional \& Islamic Banks in Hyderabad Pakistan
}

\author{
Abdul Adeel \\ MBA Scholar Mehran University Institute of Science Technology \& Development \\ Waqar Ahmed Sethar \\ Lecturer Mehran University Institute of Science Technology \& Development \\ Dr. Asif Ali Shah \\ Associate Professor Mehran University Institute of Science Technology \& Development
}

\begin{abstract}
In present market scenario where competition forces the firms to introduce new products in order to be competitive and profitable in uncertainties, financial institutions offering car financing are facing tough competition. In order to maintain their market share they offer different options for car financing for different types of customers. This study aimed to find out factors influencing car finance behavior and investigates whether religiosity play any significant role for selecting a religion oriented financial product. Theory of planed behavior was applied to assess whether religious beliefs affect the car financing decision? Primary data of 200 walk-in customers of conventional and Islamic banks (located on different sites of Hyderabad, Pakistan) were collected through non-probability (convenience) sampling. The results showed that the intention to opt for Islamic car finance is heavily influenced by religiosity. While on the other hand perceived behavioral control strongly influences the intention to finance a car from conventional banks. This research confirmed the hypotheses where Perceived Behavioral Control (PBC) affects the intentions of customers of conventional banks while in the case of Islamic finance the hypothesis the effects of PBC on intentions of customers of Islamic Banks is rejected.
\end{abstract}

Keywords: - Conventional and Islamic Banking, Customer, Religiosity Theory of Planned Behavior, Car Financing, partial least squares (PLS).

DOI: $10.7176 /$ RJFA/10-24-12

Publication date: December $31^{\text {st }} 2019$

\section{INTRODUCTION:}

The importance of the financial system increases with the passage of time as countries are moving towards economic development. As the economy becomes wealthier, the financial sector becomes larger. People need to borrow funds from the financial institutions to purchase those assets which they want. Car financing is one the facility of both system; Islamic banks use the word "Ijara" for this. It is essential for both systems to know the factors that influence their demand and buying behavior of the customers.

In this fast world the managing of personal and professional life is very difficult and if you do not have your personal transportation life can become more hectic. To make their life easier peoples always try to find a reliable mode of transportation. Car is considered more important because it is a secure mode of transportation, but everyone has not financially stable and capable of purchasing their car. To fulfill their requirements of a car they go towards the banks and obtain a car loan for the long and short term payment. Dual banking systems are working in Pakistan which means one product is offered by two different financial institutions with different policies. In Pakistan, Conventional banks and also Islamic banks provided car loan facility to peoples with some agreement. The main difference between conventional and Islamic banks is interest (Riba). Pakistan is an Islamic country and in Islam Interest is not allowed, but both Islamic and conventional banks have their followers.

Currently, 45 banks are working in Pakistan in which five banks are purely Islamic banks, and other 17 have started their operations to provide Islamic banking services after seeing the high potential rate of growth of Islamic banking sector.A car loan is a personal loan for the specific purpose for buying a new or used car customer to borrow money from a bank and agrees to repay with the specified period. It's usually 12 months to 7 years customer will repay the amount that borrows from the bank with some interest. The end users of the system are people, so it is necessary to seek out what they want and which factors affect their decisions.

The paper begins by presenting the relevant background to put our research in the context of Islamic and conventional financing Literature. The results and data analysis from the survey the paper concludes with implication, limitations, and future research direction.

\section{MOTIVATION OF RESEARCH}

- The primary motivation of the study is that now a day's auto loans are a highly demanding product of 
banks. According to the latest data of "SBP" In 2017 Auto loans are must be doubled, and auto sale is recorded matching growth of $60 \%$ as compared to last year (Azam, 2017).

In 2025 Pakistan becomes an Islamic financial hub; about $76 \%$ of people are choosing Islamic banking

(Hanif, 2018). Islamic banking has been growing rapidly and has captured more market shares in car financing; therefore, this research is attempting to identify the factors contributing to car financing.

If we look at the performance of banks in respect of car financing the Islamic banking growing very fast within the last ten years. In Pakistan, the Islamic banking system was increased very fast as compared to conventional banking. (Mobeen, 2015) Argue that auto finance had recorded growth of 32\% in September 2015 as against the $28 \%$ figure seven years ago we anticipate that auto financing as growing in the next quarter as the automobile industry stands to profit and enhanced macroeconomics and banks appetite to lend.During the quarter of April to June 2018, the total assets of Islamic banking industry enhanced to Rs. 2,482 billion by end June 2018 which shows the increment of Rs. 148 billion.

Moreover, the Islamic banking industry deposits increased by Rs 117 billion and it has touched to 2,033 billion by end June 2018. Market share of the assets of Islamic banks is 12.9 percent, and the market share of Islamic banking deposits are 14.8 percent by the end of June 2018. Furthermore, on the profitability side, the profit before tax of Islamic banking was recorded Rs. 12 billion in June 2017 and in June 2018 it increased to Rs. 15 billion.

Conventional banks charged some interest in their products but on other side Islamic banks did not charge interest. However, many factors influence the behavior of customers to finance their car from banks. To find out the factor which is influencing the intention of customers we sated the objectives that are:

$>$ To identify the factors affecting car financing through Conventional and Islamic banks.

$>$ To investigate customer behavior in selecting car financing through Islamic or conventional banks.

$>$ To compare the results of both Conventional and Islamic Banks.

\section{THEORETICAL FRAMEWORK;}

Theory of planned behavior (TPB): The TPB model has been used in many research and supported by studies on consumption and psychological related studies which was conducted by (Ajzen, 1988). It seems that has found to be an essential model in predicting intention towards Islamic financing adoption among Non-users. Using TPB hence found that Islamic finance institution constantly increases the information and understanding of non-users about Islamic financing and its products differences as conventional financing. Religion obligation was found to be a strong impact on the attitude of customers. Subjective norms also play an essential role in influencing the non-user intention of Islamic financing (Jaffar \& Musa, 2016).

Other researchers have been using TPB in social networking websites; their findings show that social norms are become acceptable and followed by the youth of our society leading to the modernization of traditional society. The youth of our society is interested in using social networks and leading to modernizing the social system and youth like to be social behavior pattern to the usage of social networks can be used in Pakistan (Tariq, Sajjad, Usman, \& Amjad, 2017).

Ajzen(2015) found determinants of the consumer attitude and behavior to food consumption decision through TPB approach he concluded that the consumer behavior is based on attitude, subjective norms and perceived behavioral to obtain or use of a single product or single product but different brands, therefore consumer decision is based on their attitude and beliefs towards brands and products.

Fig: 1 shows the conceptual foundations of the Theory of Planned Behavior which is applied in the current study.

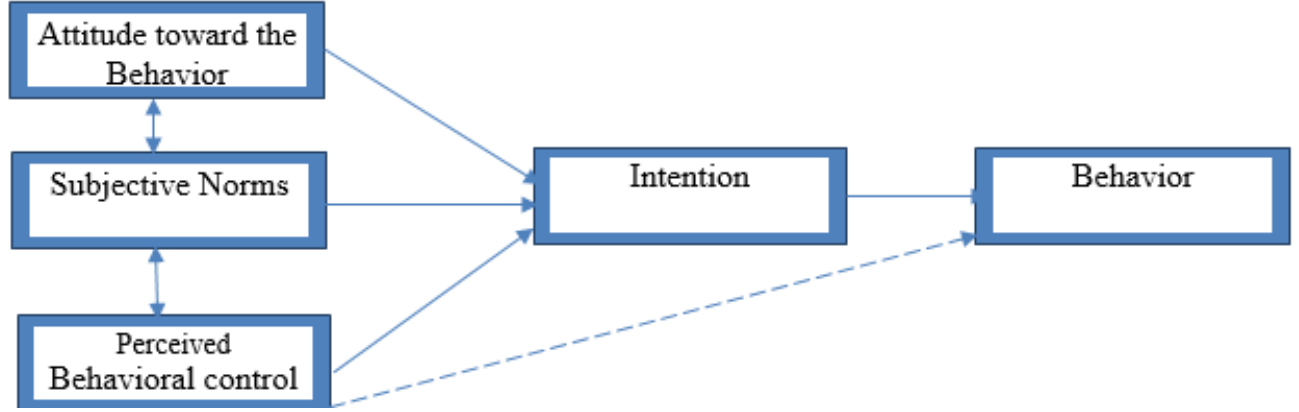

Fig .1: Source: Aijzen (1991)

\section{LITERATURE REVIEW:}

Now days, the banking industry has been changing at a higher rate and has been offering several regulations for 
the common people to provide ease to them. It has been assessed that the banking industry is expected to grow and expand its operations by being more dynamic and competitive. According to Khediri, Charfeddine, \& Youssef (2015), the banks have been examining the customer needs and want for a long time and have been implementing different strategies to be more profitable and competitive in the market. The industry has become more competitive due to the increasing number of competitors and different factors that can affect the car financing. It has been assessed that Islamic banking is referred to as the unique system of banking that is different from the conventional system because it is based on the Sharia governing system. It is based on the economics, social, political and cultural aspects of Islamic societies according to Shah, Shaikh, \& Shaikh (2017). It is due to the reason that it provides the legal framework of working that is based on the halal system. Islamic banking is referred to the banking system that is based on the Islamic laws and regulations that is also known as Shariah laws. All the principles governing the system are based on the Islamic way.

According to the analysis of Abubakar\&Aduda (2017), the Islamic banking provides great flexibility to its consumers through the methods of Islamic financing such as Ijarah (leasing), BaiBithamanAjil (differed payment), mudharabah (profit sharing), musharakah (partnership), etc. The methods of Islamic banking have started in the year 1970s and have been practiced in different countries around the globe. Additionally, the countries have also developed the Islamic banking act 1983 that was referred to the first Islamic banking system to be established for the financial institutions.

The consumers who are not having the feasibility of purchasing the new vehicles go for the vehicles financing through different Islamic and conventional banks that offer different rates and offers for purchasing the vehicle. The consumers are offered different kinds of financing for the vehicles that are referred to as the direct and indirect methods of financing and lending (Tariq, Sajjad, Usman, \& Amjad, 2017). In order to go for direct lending, the consumer's option of banks and credit unions for lenders and apply for the loan afterward. The consumers who option for the direct methods of financing often gain specific interest rates along with the commitment letter with the dealers for buying an automobile. Moreover, according to MasudRana, Hossain\&Rekha (2016) the indirect financing is also based on the dealer's arranged financing methods. Here, the dealers collect a variety of information regarding the financing methods and the methods of repayment that can be evaluated on different terms of repayment. Several consumers option for the direct methods of financing through the Islamic and conventional methods of financing (Mat et al., 2016). According to the analysis of Hanif (2018), there is a significant difference between the perception of the people towards the methods of Islamic and conventional banking due to the difference in style and methods of financing used for the particular method. It is due to the reason that the consumers are willing to carry out the methods of financing through halal methods. The consumers in the Muslim countries look forwards for the ways that can be effective and can follow the Islamic ways of providing the financial services for their car financing. It has been observed that human behavior changes concerning the methods of financing and have opportunities for competing in the global market.

Theory of planned behavior: This review features the number of authors that implement the TPB in extant literature. It also understood and showed concern for the Islamic teachings discussed on religiosity as an essential variable.

The findings of (Reni \& Ahmed, 2016) shows that the Theory of reason action (TRA) and Theory of planned behavior (TPB) attitude, subjective norm, religion, Knowledge and government support considerably effect on intention of customer to select Islamic banking product Pricing however is not significant customers have that positive attitude towards Islamic banking products in Indonesia. According to (Alam, Janor, Zanariah, Aniza, \& Ahsan, 2012) the TPB components like attitude, preserved behavior are important factors that indicate the religiosity influence on the intention of Muslims to adopt Islamic home financing in Klang Valley Malaysia.

(Ab Aziz, Wan Abdullah, \& Shukor, 2013) Conclude that Islamic auto financing is based on Islamic shariah and law which is different from conventional banks system. Islamic banks will have to compete based on to provide flexibility and high-quality product offered to its customers in order to gain their competitive advantage against their competitor in Malaysia. (Bodibe, Chiliya, \& Tarisayi, 2016) argue that Social norms and community influence has straightforwardly impact on consumer decision towards Islamic banking; thus the product knowledge has no direct impact on thoughts of consumer towards Islamic financing.(Joseph \& Kamble, 2011) Conclude that one of the most important factors that influence the purchase of passenger cars in India is the most availability of auto finance or consumer credit. Financing companies need to provide quality service in minimum time this may be possible by launching the transparent scheme and training the staff. Low-interest rate and absence of hidden charges emerge the most important factor of a consumer while choosing a finance company.

(Razi, 2014) Argue that in Pakistan the common man did not afford Islamic financing leasing if he has lack of resources if he purchases something the way of ijara he does not find any difference of the total cost between conventional and Islamic leasing mode. In Islamic leasing, mode customer has to pay the amount in the name of rent which is not equal the amount of interest of conventional banks but also higher than the current market trends. 


\section{Understanding Buying Intentions through theory of planned behavior}

Theories including theory of planned behavior (TPB) (Ajze, 1988) and theory of reasoned action by (Ajzen and Fishbein, 1975) postulate that the behavior of people is determined by intentions, where intention is defined as "Individual's readiness to buy a certain product" (Aijzen, 1991). It's a probability that the individual will perform certain behavior, thus intentions leads towards actual behavior. Madan and Yadav (2018) in their study suggested that positive intentions lead toward actual purchase behavior. According Aijzen and Fishbein (1975) behavior is most effectively predicted by intentions, so stronger intentions means that the particular behavior will be performed.

\section{Attitudes and Intentions}

Attitude is defined as set of beliefs, behavioral tendencies, feelings towards certain events, symbols, groups, socially important objects (Hogg and Vaughan, 2005). It is psychological feeling of favoring or disfavoring entities. Attitudes are used to predict intentions and behaviors of people; much of literature suggests that attitudes affect the choice towards certain products and services (Md Taib et al., 2008; George, 2002). Positive attitudes will develop positive intentions and the customer will likely purchase that product or service (Amin et al., 2011). Based on past research the following hypothesis is developed.

H1: Attitudes positively effects the intention to Purchase Car from Islamic Banks

\section{Perceived Behavioral Control}

PBC refers to perception of individuals to perform certain behavior to a certain extent (Aijzen, 1991). Underlying assumption for such behavior is relative ease or difficulty to perform that behavior (Aijzen, 2002). If individual thinks that within his means certain behavior is easy to perform the behavior will be strong. The difference between attitude and $\mathrm{PBC}$ is degree of control over a certain behavior and not the probability. Aijzen defines PBC "Perceived Control over the Performance of a behavior". In this sense PBC is perception of ease or difficulty associated with getting information about the product or services. So hypothesis is developed to test the effect of PBC on Purchase Intentions:

H2: The PBC has positive effect on the intentions to Purchase Car from Islamic Banks

\section{Social Norms}

The social norms is a social pressure to which effects the intentions to perform certain behavior, social expectation influence the behavior where individuals are under the social expectation will perform the particular behavior in question. If social pressure is to not to perform particular behavior people will less likely perform that behavior, in this present study if Islamic car finance is seen as socially desirable behavior people will likely opt for car finance from Islamic banks. In that given context the following hypothesis is therefore proposed. H3: The Social Norms have positive effect on the intentions to purchase car from Islamic Banks

\section{Perceived Religiosity}

Religious affiliations have been explored by the researchers in different situations, religious affiliations, obligations associated with relation, commitments etc Sun et al., and (2012). People's habits, attitudes, feelings and moral values are determined by religion (Mokhlis, 2009). Religion also shapes knowledge, beliefs, and attitudes. Many authors have showed that religiosity affects the consumer's choice of services, products and their consumption patterns and information (Echachabi and Aziz, 2012, Mokhlis, 2009). Religion also affects the attitude of people towards certain products and services (Wan Ahmad et al, 2008). Individuals with deep religious knowledge will perform behaviors in conformity with their religious beliefs (Ahmad et al., 2008). Based on the above discussion it could be said that religious people are more likely to purchase different products and services from Islamic banks. Following that discussion the following hypothesis is proposed: H4: Perceived religiosity has a positive effect on intentions to purchase car from Islamic Banks

\section{METHOD SAMPLE \& PROCEDURE:}

The sampling frame to use in this study was distributed to customers of Islamic and conventional banks that obtain car financing from them in Hyderabad Sindh. In gathering the primary data, we had personally distributed the survey questionnaires to 210 respondents from which 161 fill our questionnaire. We choose three most popular conventional and three Islamic banks in Hyderabad due to large business center within the area. Survey questionnaires were personally distributed and collected from the respective respondents, yielding a response rate of 70 percent. The technique of sampling is used in this study was non-probability convenience sampling. 
Table: 1 Sampling Profile.

\begin{tabular}{|c|c|c|c|c|c|}
\hline \multicolumn{3}{|c|}{ Demographic Profile Respondent of Islamic banks } & \multicolumn{3}{|c|}{$\begin{array}{c}\text { Demographic Profile Respondent of Conventional } \\
\text { banks }\end{array}$} \\
\hline Gender & Frequency & $\%$ & Gender & Frequency & $\%$ \\
\hline Male & 55 & 67. & Male & 61 & 76.3 \\
\hline Female26 & 32.1 & & Female & 19 & 23.8 \\
\hline Age profile & Frequency & $\%$ & Age profile & Frequency & $\%$ \\
\hline $25-3023$ & 28.4 & & $25-30$ & 18 & 2.5 \\
\hline $30-3526$ & 32.1 & & $30-35$ & 29 & 36.3 \\
\hline $35-4020$ & 24.7 & & $35-40$ & 24 & 30.0 \\
\hline $40-4509$ & 11.1 & & $40-45$ & 6 & 7.5 \\
\hline $45-5003$ & 3.7 & & $45-50$ & 3 & 3.8 \\
\hline Religion profile & Frequency & $\%$ & Religion profile & Frequency & $\%$ \\
\hline Non-Muslim & 18 & 22.2 & Non-Muslim & 24 & 30.0 \\
\hline Muslim & 63 & 77.8 & Muslim & 56 & 70.0 \\
\hline $\begin{array}{l}\text { Education } \\
\text { Profile }\end{array}$ & Frequency & $\%$ & $\begin{array}{l}\text { Education } \\
\text { profile }\end{array}$ & Frequency & $\%$ \\
\hline Intermediate & 1 & 1.3 & Intermediate & 3 & 3.7 \\
\hline Bachelor's & 41 & 51.2 & Bachelor's & 38 & 46.9 \\
\hline Master's & 34 & 42.5 & Master's & 38 & 46.9 \\
\hline MPhil & 2 & 2.5 & MPhil & 1 & 1.2 \\
\hline $\mathrm{PhD}$ & 2 & 2.5 & $\mathrm{PhD}$ & 1 & 1.2 \\
\hline $\begin{array}{l}\text { Employment } \\
\text { Profile }\end{array}$ & Frequency & $\%$ & $\begin{array}{l}\text { Employment } \\
\text { Profile }\end{array}$ & Frequency & $\%$ \\
\hline Self-Employed & 66 & 81.5 & Self-Employed & 63 & 78.8 \\
\hline Own-Business & 15 & 18.5 & Own-Business & 17 & 21.3 \\
\hline Income Profile & Frequency & $\%$ & Income Profile & Frequency & $\%$ \\
\hline $25,000-50,000$ & 19 & 23.5 & $25,000-50,000$ & 19 & 23.8 \\
\hline $50,000-75,000$ & 47 & 58 & $50,000-75,000$ & 39 & 48.8 \\
\hline $75,000-100,000$ & 15 & 18.5 & $75,000-100,000$ & 22 & 27.5 \\
\hline Bank Profile & Frequency & $\%$ & Bank Profile & Frequency & $\%$ \\
\hline Bank Islami & 19 & 23.5 & Bank-Alfalah & 17 & 21.3 \\
\hline Dubai Islamic & 20 & 24.7 & Habib Bank & 28 & 35.0 \\
\hline Meezan Bank & 42 & 51.9 & MCB Bank & 35 & 43.8 \\
\hline Car Range & Frequency & $\%$ & Car Range & Frequency & $\%$ \\
\hline Low Range & 32 & 39.5 & Low Range & 22 & 27.5 \\
\hline Medium Range & 23 & 28.4 & Medium Range & 22 & 27.5 \\
\hline High Range & 26 & 32.1 & High Range & 36 & 45.0 \\
\hline
\end{tabular}

From the total respondents that took part in this study majority males. In addition, non-Muslim customers are more than an Islamic bank as a camp is to conventional banks. Most of the respondents are within the age groupof 30- 40 . 
QUALITY ASSESSMENT OF PLS-SEM MODEL

Table: 2 Quality Assessment test PLS-SEM

\begin{tabular}{|c|c|}
\hline \multicolumn{2}{|c|}{ Multicollinearity for Conventional Banks } \\
\hline & VIF \\
\hline ATB_1 & 1.65 \\
\hline ATB_2 & 2.627 \\
\hline ATB_3 & 2.172 \\
\hline ATB_5 & 1.659 \\
\hline IN1 & 3.162 \\
\hline IN2 & 4.445 \\
\hline IN3 & 3.745 \\
\hline IN5 & 1.664 \\
\hline PBC1 & 1.649 \\
\hline PBC2 & 1.953 \\
\hline PBC3 & 1.893 \\
\hline PBC4 & 1.419 \\
\hline SN1 & 1.766 \\
\hline SN2 & 2.429 \\
\hline SN4 & 2.966 \\
\hline SN5 & 3.524 \\
\hline
\end{tabular}

\begin{tabular}{|lr|}
\hline \multicolumn{2}{l}{ Multicollinearity for Islamic banks } \\
\hline & \\
\hline & VIF \\
ATB_2 & 1.687 \\
ATB_3 & 3.279 \\
ATB_4 & 3.701 \\
IN1 & 2.469 \\
IN2 & 3.386 \\
IN3 & 3.523 \\
IN5 & 1.915 \\
PBC1 & 2.127 \\
PBC2 & 2.07 \\
PBC3 & 2.327 \\
PBC6 & 1.596 \\
R1 & 1.799 \\
R2 & 3.276 \\
R3 & 2.497 \\
R4 & 4.298 \\
SN3 & 2.012 \\
SN4 & 1.961 \\
SN5 & 2.107 \\
\hline
\end{tabular}

The table above validates the variables of study that there is no substantial degree of accuracy it can be determined that variables of the study do not have a correlation with each other or predictive power to predict each other on the highest degree of accuracy.

Figure: 2 PLS-SEM Model Islamic banking

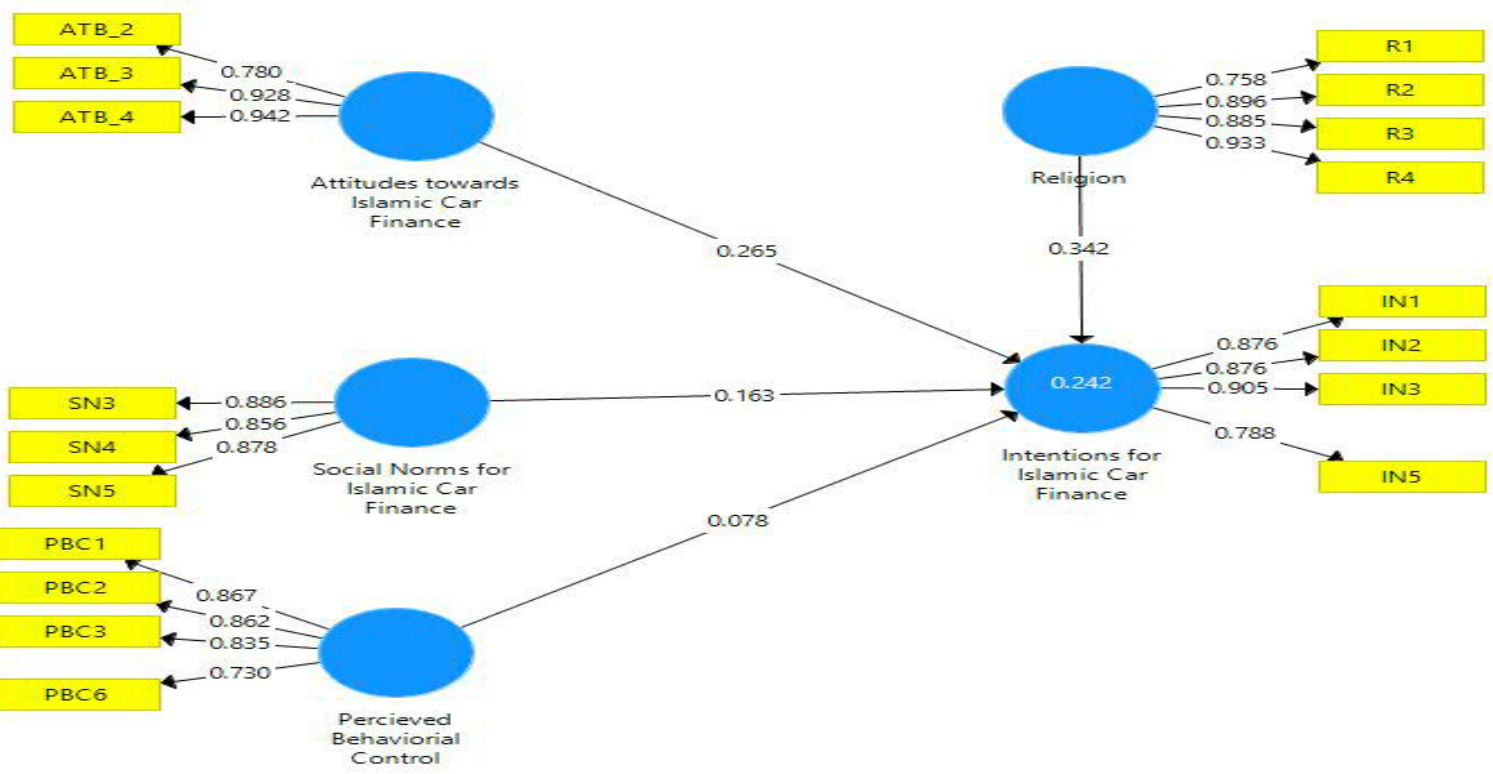

PLS-SEM model for Islamic Banking

- $\quad$ The above model illustrates that all the indicators exceeding the criteria 0.7

- The core concept of reliability is that an instrument must produce same results same surveyed twice from the same group of respondents under the same controlled or open conditions. Meanwhile, an author used a threshold of 0.7 to analyze whether there is internal consistency in the data or not (Chang and Chuang, 2011) since, the following study has four variables, and each variable has higher Cronbach's alpha greater than 0.7 ; hence it can be stated that there is internal consistency in the responses. The range of AVEs for the constructs is 0.786 to 0.763 . Hence they satisfy the requirement. Therefore, the data is reliable to be used for further analysis for study since it meets with reliability criteria. 
Table: 3 Discriminant validity for Islamic banks

\begin{tabular}{|l|l|l|l|l|l|}
\hline & $\begin{array}{l}\text { ATB Islamic Car } \\
\text { Finance }\end{array}$ & $\begin{array}{l}\text { INT Islamic Car } \\
\text { Finance }\end{array}$ & $\begin{array}{l}\text { PBC Islamic Car } \\
\text { Finance }\end{array}$ & Religion & $\begin{array}{l}\text { SN Islamic Car } \\
\text { Finance }\end{array}$ \\
\hline $\begin{array}{l}\text { ATB Islamic Car } \\
\text { Finance }\end{array}$ & $\mathbf{0 . 8 8 6}$ & & & & \\
\hline $\begin{array}{l}\text { INT for Islamic Car } \\
\text { Finance }\end{array}$ & 0.281 & $\mathbf{0 . 8 6 2}$ & & & \\
\hline $\begin{array}{l}\text { PBC for Islamic Car } \\
\text { Finance }\end{array}$ & 0.098 & 0.189 & $\mathbf{0 . 8 2 5}$ & & \\
\hline Religion & -0.13 & 0.318 & 0.117 & $\mathbf{0 . 8 7}$ & \\
\hline $\begin{array}{l}\text { SN for Islamic Car } \\
\text { Finance }\end{array}$ & 0.318 & 0.271 & 0.272 & 0.007 & $\mathbf{0 . 8 7 3}$ \\
\hline
\end{tabular}

- The test ensures that there is a strong relationship of construct exists with the indicators which have been prerequisites for the analyzing relationships between the latent relationships that values of relationship are greater than 0.8 and are near to 1 ; hence relationships can be stated as strongest. This indicates that variables of Islamic banking have the strongest relationships with constructs, which make variables liable to analyze the relationship between latent variables of the study.

BOOTSTRAPPING RESULTS (HYPOTHESIS AND SIGNIFICANCE FOR ISLAMIC BANKS) Table: 3 Boot Strapping

\begin{tabular}{|c|c|c|c|c|c|c|}
\hline - & $\begin{array}{l}\text { Original } \\
\text { Sample } \\
\text { (O) }\end{array}$ & $\begin{array}{l}\text { Sample } \\
\text { Mean } \\
\text { (M) }\end{array}$ & $\begin{array}{l}\text { Standard } \\
\text { Deviation } \\
\text { (STDEV) }\end{array}$ & $\begin{array}{l}\text { T Statistics } \\
(\mid \mathbf{O} / \text { STDEV } \mid)\end{array}$ & $\begin{array}{l}\mathbf{P} \\
\text { Values }\end{array}$ & \\
\hline $\begin{array}{l}\text { Attitudes towards Islamic } \\
\text { Car Finance -> Intentions } \\
\text { for Islamic Car Finance }\end{array}$ & 0.265 & 0.278 & 0.116 & 2.291 & 0.022 & Accepted \\
\hline $\begin{array}{l}\text { Perceived Behavioral } \\
\text { Control -> Intentions for } \\
\text { Islamic Car Finance }\end{array}$ & 0.078 & 0.097 & 0.123 & 0.64 & 0.522 & Rejected \\
\hline $\begin{array}{l}\text { Religion -> Intentions for } \\
\text { Islamic Car Finance }\end{array}$ & 0.342 & 0.351 & 0.092 & 3.717 & 0 & Accepted \\
\hline $\begin{array}{l}\text { Subjective Norms for } \\
\text { Islamic Car Finance -> } \\
\text { Intentions for Islamic Car } \\
\text { Finance }\end{array}$ & 0.163 & 0.162 & 0.116 & 1.405 & 0.161 & Rejected \\
\hline
\end{tabular}

- As can be seen that from the above-proposed hypotheses two are accepted at a comfortable level of significance except two. It can be revealed from the following hypothesis that perceived behavioral control, and subjective norms did not make any significant impact in Islamic car financing, and it is not significant to the path coefficient.

- The overall $R^{2} 0.242$ is moderate-low suggesting the model is meaningful in explaining the intention to participate concept.

Figure: 3 SME-PLS Conventional Banking model

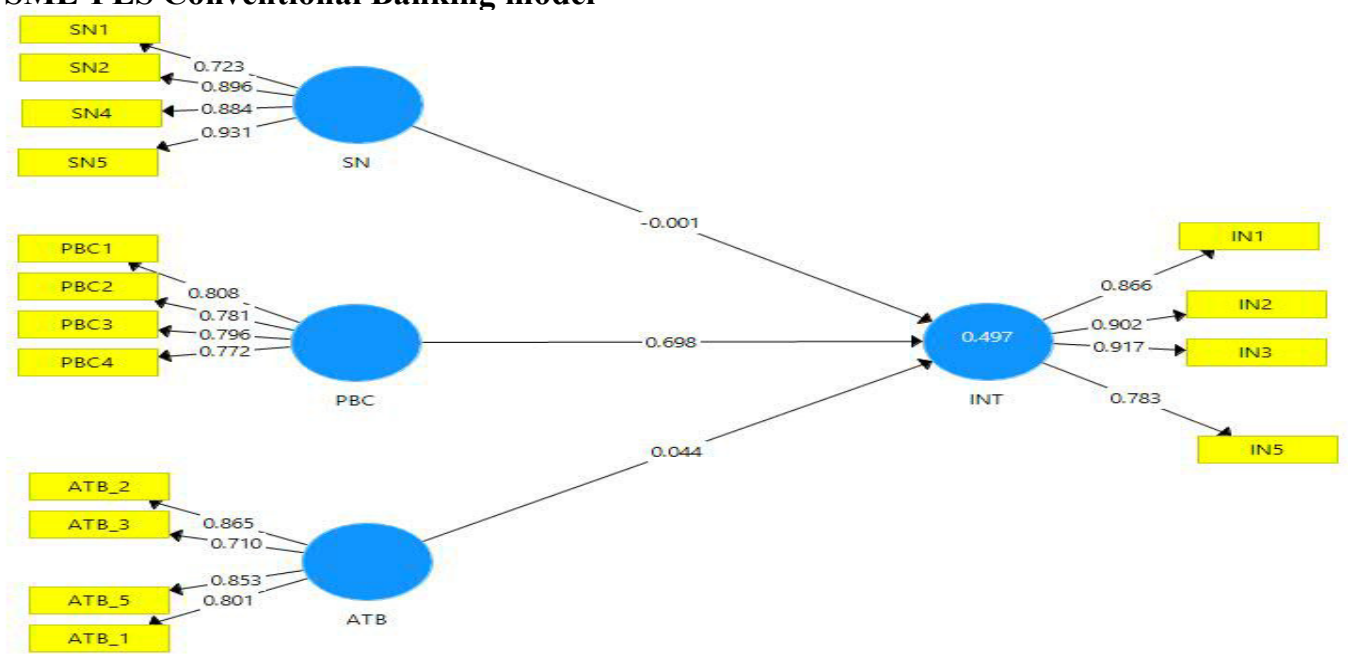




\section{PLS-SEM model for Conventional Banks}

- The above model illustrates that all the indicators are exceeding the criteria 0.7 . On the other hand, the data also comply with the reliability analysis; see results of Cranach's alpha below.

- The following study has four variables, and each variable has higher Cronbach's alpha greater than 0.7; hence it can be stated that there is internal consistency in the responses. The range of AVEs for the constructs is 0.65 to 0.744 . Hence they satisfy the requirement. Therefore, the data is reliable to be used for further analysis for study since it meets with reliability criteria.

Table: 4 Discriminant validity test for conventional banks

\begin{tabular}{|l|r|r|r|r|}
\hline & \multicolumn{1}{|c|}{ ATB } & \multicolumn{1}{|l|}{ INT } & \multicolumn{1}{|l|}{ PBC } & SN \\
\hline ATB towards conventional banks & $\mathbf{0 . 8 1}$ & & & \\
\hline INT towards Conventional banks & 0.145 & $\mathbf{0 . 8 6 8}$ & & \\
\hline PBC towards Conventional banks & 0.144 & 0.704 & $\mathbf{0 . 7 8 9}$ & \\
\hline SN towards Conventional banks & 0.045 & 0.246 & 0.351 & $\mathbf{0 . 8 6 2}$ \\
\hline
\end{tabular}

The above table shows discriminant validity for conventional banks which measures the relationship of the construct with its indicators. Meanwhile, the test ensures that there is a strong relationship of construct exists with the indicators which have been prerequisites for the analyzing relationships between the latent relationships. Furthermore, all variables have the strongest relationship with its predictors given that values of relationship are greater than 0.8 and are near to 1 ; hence relationships can be stated as strongest. This indicates that variables of conventional banking have the strongest relationships with constructs, which make variables liable to analyze the relationship between latent variables of the study.

Table: 5 Bootstrapping Results (Hypothesis and Significance for conventional Banks)

\begin{tabular}{|l|r|r|r|r|r|r|}
\hline & $\begin{array}{c}\text { Original } \\
\text { Sample (O) }\end{array}$ & $\begin{array}{c}\text { Sample } \\
\text { Mean (M) }\end{array}$ & $\begin{array}{c}\text { Standard } \\
\text { Deviation } \\
\text { (STDEV) }\end{array}$ & $\begin{array}{c}\text { T Statistics } \\
(\mid \mathbf{O} / \text { STDEV } \mid)\end{array}$ & $\begin{array}{c}\text { P } \\
\text { Values }\end{array}$ & \\
\hline ATB -> INT & 0.044 & 0.054 & 0.119 & 0.373 & $\mathbf{0 . 7 0 9}$ & Rejected \\
\hline PBC -> INT & 0.698 & 0.693 & 0.061 & 11.375 & 0 & Accepted \\
\hline SN -> INT & -0.001 & 0.023 & 0.079 & 0.013 & $\mathbf{0 . 9 9}$ & Rejected \\
\hline
\end{tabular}

- As can be seen that from the above-proposed hypotheses one is accepted at a comfortable level of significance and the other two hypotheses are rejected at significance level. It can be said that attitude and social norms did not make any significant impact and it is not significant to the path coefficient.

- The overall $R^{2} 0.497$ is moderate- suggesting the model is meaningful in explaining the intention to participate concept.

\section{COMPARATIVE ANALYSIS OF CONVENTIONAL \& ISLAMIC BANKING CAR FINANCING THROUGH THEORY OF PLANNED BEHAVIOR.}

- The demographic data of this research shows that people with a high level of income involved in car financing from conventional banks and prefer a high range of the car. Majority of them are from working-class group. The contribution of the male is high in both Islamic and conventional bank car financing.

- The demography of Islamic bank shows that the majority of working class prefer low range car in Islamic car financing. Certainly, the main factor responsible for this attitude is the respondent level of income and the interest rate offered by the Islamic and conventional banks.

- The percentage of non-Muslims in Islamic bank car financing is $22 \%$ which is lower than conventional bank car financing that comprises of $30 \%$.

- In the following research, the theory of planned behavior is used to determine the behavior of consumer towards Islamic and conventional car financing. The findings revealed from the data empirically supported the theory of planned behavior.

- All of the hypothesis drives to measure the intention of consumer towards Islamic and conventional car financing, namely attitudes, subjective norms, and perceived behavior have been shown to have significant path coefficients to intentions.

- Further insights have been provided by the use of religiosity as controls. It formed a positive relationship between the behavior of the consumer and its intention towards Islamic car financing.

- Comparatively, Religion constitutes the primary difference between conventional and Islamic banks car financing them. 
- As well as, the study depicted that Attitude is an essential factor in influencing people intention in undertaking the Islamic car financing because those with high positive attitudes appeared to have greater intentions to undertake the Islamic car financing facility.

- Regarding the perceived behavior, there is no direct and significant relationship to undertake Islamic car financing. Therefore, H2 was not supported in Islamic bank car financing. on the other side, perceived behavior formed a significant relationship with intention in conventional bank car financing

- On the contrary, the attitude has no significant relationship with the intention in conventional bank car financing. Hence, $\mathrm{H} 1$ was rejected in conventional car financing as compared to Islamic bank car financing.

- However, the subjective norm which constitutes the H4 in the following study is rejected in both conventional and Islamic bank car financing. Therefore, the subjective norm does not have any significant contribution with intention.

- Moreover, the possible explanation on this matter is that the respondents have knowledge and awareness about the conventional and Islamic car financing. They can make decision-based on their own experience, knowledge, income and considering little about others' opinion.

- The consumer of conventional banking and Islamic Banking have the only intention that conventional banking is used by consumers with the only objective to get the process complete in a short period.

- On the other hand, consumer of Islamic bank does not have these intentions; instead, they have a faith relationship with the banking which enables them to live on the safe side and avoid mistreating the Islamic laws of interest and illegal activities.

- Regardless of all the benefits offered by Islamic banks, still the pace of Islamic banks car financing is lower than conventional banks car financing but, in the light of all the above factors, it can be concluded that in future the scope of Islamic car financing will grow more and gain more market than conventional banking.

\section{Discussion}

The purpose of conducting the research was to determine the factors that affect the intention of the customer and constitute their behavior towards conventional and Islamic car financing. The research had been conducted based on the theory of planned behavior to determine the intention and behavior of customers. The theory of planned behavior consists of attitude towards the behaviors, subjective norms, perceived behavioral, intention and its influence on behavior.

The study had been conducted through by distributing the questionnaire to the customers that had acquired car financing from Islamic and Conventional bank. The analysis of data had been done through the use of PLSSEM model in which it had been found that the perceived behavior has a significant impact on the Intention of the customer to obtained conventional car financing.

The study also confirmed that religion and Attitude towards behavior has a significant impact on Customer decision towards Islamic car financing. The relation is positive which mean the more significant Impact of explaining variability in behavior is not unusual.

Regarding the subjective norms, there is no direct and significant relationship with Intention to undertake the Islamic and Conventional car financing. Therefore $\mathrm{H} 2$ of conventional and Islamic was not supported; however this finding counterpart with (Aalam, Zanor, Zanariah, Che, Wel, \& Ahsan, 2012). Therefore, the difference between Islamic and conventional car financing is a religion which encourages customers to go for Islamic car financing whereas the perceived behavior controls persuade the customers to going for conventional car financing.

\section{LIMITATIONS:}

This study faced a numbers of limitations; Firstly data for of this study is obtained from only three top ranking and most popular banks in Hyderabad. If all banks were examine the result could have been more generalized, second the study focus only on consumer behavior intention. Therefore future researcher of this dimension needs to know the actual functions of Islamic and conventional banks, and have to know about the main purpose of providing services to customers and marketing strategies to target individuals to use Islamic and conventional banking. Religious compulsion and social influence could be examined differently to draw certain results relating to the attitude towards Islamic and conventional banking.

\section{SUGGESTIONS \& RECOMMENDATIONS:}

As expected, based on the findings, it appears that the TPB model acts as an active component in predicting the 
intention of undertaking conventional and Islamic car financing among people in Hyderabad. Based on the above results and discussion, few recommendations had been provided to the conventional banks and Islamic banks regarding financing. The following are the recommendations:

- Islamic banks need to provide their car loan services to the Muslim countries as based on the results; the factors that motivate the customer for going for Islamic car financing are religion and perceived behavioral control. This provides an opportunity for Islamic banks to offer their car services to Muslim countries.

- An Islamic bank needs to increase its marketing portfolio and also introduce new ideas of the mode of leasing to capture the market.

- The conventional banks have the opportunities in promoting its car loaning services to the non-Muslim people as the factors that have been influencing the decision-making behavior that are based on the theory of planned behavior is perceived behavior. Therefore, the conventional banks can highly promote its car loaning service to the non-Muslims.

- For persuading the decisions of the customers, the banks can lower its mark upon car financing to attract more customers.

- Mostly, medium and small range cars are preferred by normal and medium income groups. It can be suggested that automobile companies should have to make their cars below than one million so that every person would easily afford it.

- The Government of Pakistan can play an important role in car financing as by providing compensatory benefits to the first time buyers of the Islamic and conventional bank car financing through its policies.

\section{REFERENCES}

1. Statistics. (2019). Global Islamic banking assets by country 2017 | Statistic. [Online] Available at https://www.statista.com/statistics/649269/distribution-of-global-islamic

2. Sbp.org.pk.(2019).[online]Availableat:http://www.sbp.org.pk/ibd/bulletin/2018/Jun.pdf

3. Statistics. (2019). Islamic finance banking in London 2016 | UK statistic. [Online] Available at https://www.statista.com/statistics/324126/uk-islamic-finance-banks-london.

4. Arifeen, M. (2018). Boom In Consumer Financing Through Banks. Pakistan\&Gulf Economist.

5. Hanif, U. (2018). Pakistan Can Become a Hub Of Islamic Finance Say Experts. Express Tribune.

6. Abu-Bakr, A. S., \&Aduda, J. (2017). Islamic Banking and Investment Financing: A Case of Islamic Banking in Kenya. International Journal of Finance, 2(1), 66-87.

7. Cerović, L., SuljićNikolaj, S., \&Maradin, D. (2017). Comparative analysis of conventional and Islamic banking: Importance of market regulation. Ekonomskamisao I praksa, (1), 241-263.

8. Hair, J.F., Hult, G.T.M., Ringle, C.M., Sarstedt, M., and Thiele, K.O., (2017). Mirror, on the wall: a comparative evaluation of composite-based structural equation modeling methods. Journal of the Academy of Marketing Science, 45(5), pp.616-632.

9. Shah, D. B., Shaikh, S., \& Shaikh, D. M. (2017). The Circumstantial loaning policies of the banking sector: A case study of Hyderabad Sindh. Grassroots, vol.51, No I.

10. Riazuddin, R. (2017). Islamic Banking Bulletin. Islamic Banking Department State Bank Of Pakistan. Express Tribune.

11. Azam, M. (2017, October Monday). Banks Growing Romance With Car Industry. Retrieved from Dawn.com.

12. Tariq, J., Sajjad, A., Usman, A., \& Amjad, A. (2017). The Role of Intentions In Facebook Usage among Educated Youth in Pakistan: An Extension Of Theory Of Planned Behavior. Computer In Human Behaviour.

13. Bodibe, S., Chiliya, N., \& Tarisayi, C. (2016). The Factors Affecting Customers'Decision To Adopt Islamic Banking. Banks and Bank System.

14. Siddqui, I. (March 2016). Islamic Bank Bulletin. Express Tribune.

15. Jaffar, M. A., \& Musa, R. (2016). Determinants Of Attitude And Intention Towards Islamic Finance Adoption Among Non Users. Procedia Economics and Finance.

16. Reni, A., \& Ahmed, N. H. (2016). Application Of Theory Reasoned Action In Intention to Use Islamic Banking In Indonesia. Journal Of Islamic Economics.

17. MasudRana, M., Hossain, K., \&Rekha, R. S. (2016). Profitability and liquidity of conventional banking and Islamic banking in Bangladesh: A comparative study. IJAR, 2(9), 318-327.

18. Isa, M., \& Lee, S. P. (2016). How Islamic Bank Set Financing Charges: A Survey of People's Perception in Malaysia.

19. 20. Qayyum, D. A., Nayab, D. D.-e., Hussain, D. A., \& Qdir, U. (2016). Pakistan's Automotive Industries. Pide working Papers No: 137. 
20. Mat, A., Said, A. M., Bakar, E. A., Kori, N. L., \&Munir, Z. A. (2016). Determining the Income Differences and Complaint Behavior Among Automobile Repairs and Service.

21. Mobeen, B. (2015, November Friday). Pakistan Automobile: Auto Finance the second coming. Karachi, Sindh, Pakistan: BMA Capital Management Ltd.

22. Ali, A. I., \& Siddique, Z. (2015). Alternative to KIBOR for Islamic Banking: A case study Of Pakistan. S3H Working paper series.

23. Arshad, A., \& Shaikh, A. (2015). Car financing is revving up car sale in Pakistan. Karachi: Aurora's editorial staff.

24. Khediri, K. B., Charfeddine, L., \& Youssef, S. B. (2015). Islamic versus conventional banks in the GCC countries: A comparative study using classification techniques. Research in International Business and Finance, 33, 75-98.

25. Ajzen, L. (2015). Consumer Attitude And Behavior: Theory Of Planned Behavior Applied to Food Consumption Decision. Rivista di Economia Agraria, Anno Lxx, n.2.

26. Razi, N. (2014). Islamic Banking system And model of leasing: A Comparative Analysis in the Light Of Maqasid-al-Shari'ah. Cultural and Religious Studies.

27. Bourkhis, K., \&Nabi, M. S. (2013). Islamic and conventional banks' soundness during the 2007-2008 financial crisis. Review of Financial Economics, 22(2), 68-77. http://doi.org/10.1016/j. rfe.2013.01.001

28. Ab Aziz, M. R., Wan Abdullah, W. M., \& Shukor, S. A. (2013). A vehicle financing comparative study between Ijarah in Maybank Berhad \& Bai Bithaman Ajil In. University Sains Islam Malaysia. Research gate.net publication.

29. Alam, S. S., Janor, H., Zanariah, Aniza, C., \& Ahsan, N. (2012). Is Religiosity an Important Factor in Influencing the Intention to Undertake Islamic Home Financing In ka lang Vally. Malaysia. World Applied Science Journal.

30. Baloch, F. (2012). Car Financing: More Banks Open Up to the Idea Of Used Cars. THE EXPRESS TRIBUNE.

31. Joseph, D. A.-s., \& Kamble, D. H. (2011). Buying behavior of Passenger car customers towards auto financing. Indian journal of commerce and management studies.

32. Chang, H.H. and Chuang, S.S., 2011. Social capital and individual motivations on knowledge sharing: Participant involvement as a moderator. Information \& Management, 48(1), pp.9-18.

33. Ajzen, L., \& Fishbein. (1972). Consumer Behavior.

34. Consumers in Shah Alam, Malaysia. Procedia Economics and Finance, 37, 21-26

35. Hanif, M., Tariq, M., \& Tahir, A. (2012). Comparative performance study of conventional and Islamic banking in Pakistan. International Research Journal of Finance \& Economics, (83).

36. Salman, A., \& Nawaz, H. (2018). Islamic financial system and conventional banking: A comparison. Arab Economic and Business Journal, 13(2), 155-167.

37. Ehsan Wahla, A., Hasan, H., \& Bhatti, M. I. (2018). Measures of customers' perception of car Ijarah financing. Journal of Islamic Accounting and Business Research, 9(1), 2-16

38. Madan, K., \& Yadav, R. (2018). Understanding and predicting antecedents of mobile shopping adoption: a developing country perspective. Asia Pacific Journal of Marketing and Logistics, 30(1), 139-162.

39. Aziz, S., Md Husin, M., Hussin, N., \& Afaq, Z. (2019). Factors that influence individuals' intentions to purchase family takaful mediating role of perceived trust. Asia Pacific Journal of Marketing and Logistics, 31(1), 81-104.

40. Idris, R. A., Naziman, K. N., Januri, S. S., Asari, F. A., Muhammad , N., Sabri, S. M., \& Jusoff, K. (2011). Religious Value as the Main Influencing Factor to Customers Patronizing Islamic Bank. World Applied Sciences Journal. Vol. 12 (Special Issue on Bolstering Economic Sustainability): 8-13

41. Erol, C., \& El-Bdour, R. (1989). Attitudes, Behaviour, and Patronage Factors of Bank Customers towards Islamic Banks. International Journal of Bank Marketing. Vol. 7(6): 31-37.

42. Chhapra, I. U., Ahmed, A., Rehan, R., \& Hussain, F. (2018). Consumer's Preference and Awareness: Comparative Analysis Between Conventional and Islamic Ijarah Auto Financing in Pakistan. Al-Iqtishad: Jurnal Ilmu Ekonomi Syariah (Journal of Islamic Economics). Vol. 10 (2): 389 - 402 